\title{
FASAL 233 KONVENSYEN UNDANG-UNDANG \\ LAUT 1982: SATU ANALISIS TERHADAP PERAIRAN SELAT MELAKA
}

\section{(Article 233 Law of the Sea Convention 1982: An Analysis on the Straits of Malacca)}

Hanis Yasmin Ab Rahim

Universiti Multimedia

Wan Siti Adibah Wan Dahalan*

wsa@ukm.edu.my

Fakulti Undang-undang, Universiti Kebangsaan Malaysia

Pengarang koresponden (Corresponding author): *

Rujukan artikel ini (To cite this article): Hanis Yasmin Ab Rahim dan Wan Siti Adibah Wan Dahalan. (2021). Fasal 233 Konvensyen Undang-Undang Laut 1982: Satu analisis terhadap perairan Selat Melaka. Kanun: Jurnal Undang-undang Malaysia, 33(2), 203-218 .http://doi.org. 10.37052/kanun.33(2)no1

\begin{tabular}{|c|c|c|c|c|c|c|}
\hline $\begin{array}{l}\text { Peroleh: } \\
\text { Received: }\end{array}$ & $27 / 1 / 2021$ & $\begin{array}{l}\text { Semakan: } \\
\text { Revised }\end{array}$ & $4 / 5 / 2021$ & $\begin{array}{l}\text { Terima: } \\
\text { Accepted: }\end{array}$ & $20 / 5 / 2021$ & $\begin{array}{l}\text { Terbit dalam talian: } \\
\text { Published online }\end{array}$ \\
\hline
\end{tabular}

\begin{abstract}
Abstrak
Selat Melaka merupakan selat yang terletak di antara tiga buah negara, iaitu Malaysia, Singapura dan Indonesia. Selat tersebut berfungsi sebagai laluan terpenting bagi beratus-ratus kapal untuk melakukan pelbagai aktiviti bersifat antarabangsa terutamanya bagi tujuan perdagangan. Hal ini secara tidak langsung menyumbang kepada kesesakan trafik yang amat tinggi, meningkatkan risiko berlakunya perlanggaran dan pertembungan antara kapal yang mengundang tumpahan minyak yang akan menjejaskan biosistem laut. Sungguhpun Bahagian III dan Bahagian XII Konvensyen UndangUndang Laut 1982 (UNCLOS) diguna pakai untuk mengawal selia isu ini, Fasal 233 secara khususnya menjadi tajuk perbincangan bagi
\end{abstract}

(C) Dewan Bahasa dan Pustaka. 2021. This work is licensed under the term of the Creative Commons Attribution (CC BY) (http://creative commons.org/licenses/by/4.0/) 
mengenal pasti sejauh mana langkah penguatkuasaan dapat diambil terhadap kapal-kapal yang berbuat kerosakan. Oleh itu, artikel ini mengenal pasti konsep dan definisi Fasal 233 dan keterpakaiannya dalam membendung pencemaran laut di Selat Melaka. Artikel ini turut menganalisis pelaksanaan Fasal 233 yang telah dilakukan oleh Negara-negara Selat serta pemakaian peruntukan UNCLOS 1982 yang lain dalam menguatkuasakan undang-undang di Selat Melaka. Artikel ini turut mengemukakan beberapa cadangan bagi sebarang penambahbaikan terhadap isu pencemaran laut dan kewajipan Negara-negara Selat untuk menangani masalah yang berlaku.

Kata kunci: Fasal 233, Selat Melaka, pencemaran laut, Negara Selat, Kapal

\begin{abstract}
The Straits of Malacca is a narrow strait located between three countries, namely Malaysia, Singapore and Indonesia. The Straits functions as the most important passage for hundreds of ships to deal with international affairs, particularly for trading purposes. Such a situation indirectly contributes to high traffic congestion and increases the risk of collision between ships, which consequently causes oil spills and damages the aquatic biosystems. Part III and Part XII of the Law of the Sea Convention 1982 (UNCLOS) would be applicable in addressing such issues, particularly Article 233. Article 233 would be the main discussion applied to analyse the extent of enforcement measures that could be taken towards ships that cause damage. Therefore, this article identifies the concept and definition of Article 233 and its application in curbing the issue of sea pollution in the Straits of Malacca. It aims to identify the measures that could be taken by the littoral states and the application of other provisions under UNCLOS 1982 in enforcing the laws in the Straits. This article also proposes suggestions and recommendations to improve on the issue of sea pollution and the obligations of the littoral states in curbing the problem.
\end{abstract}

Keywords: Article 233, The Straits of Malacca, sea pollution, Straits States, ships 


\section{PENDAHULUAN}

Bahagian III Konvensyen Undang-Undang Laut Antarabangsa 1982 (UNCLOS 1982) menyediakan peraturan dan undang-undang bagi laluan selat yang digunakan sebagai laluan antarabangsa, secara langsung memberikan hak laluan transit kepada semua kapal yang melalui laluan tersebut. Mahkamah Keadilan Antarabangsa dalam kes United Kingdom v. Albania atau lebih dikenali sebagai "Corfu Channel case" menyatakan bahawa laluan selat yang digunakan sebagai laluan antarabangsa membawa elemen geografi dan berfungsi sebagai laluan yang berguna bagi trafik antarabangsa. Terdapat sebanyak 116 laluan selat yang digunakan sebagai laluan antarabangsa. Selat Melaka merupakan antara laluan selat yang paling penting kerana menghubungkan Timur Asia dengan Timur Tengah, Afrika serta Eropah (Rusli, 2012). Selat tersebut terletak di antara tiga buah negara, iaitu Malaysia, Indonesia dan Singapura. Negara-negara ini telah bersepakat untuk menangani sebarang isu berkaitan dengan navigasi dan keselamatan maritim di perairan Selat Melaka (Organisasi Maritim Antarabangsa, 2012).

Terdapat beratus-ratus buah kapal yang melalui Selat Melaka menyebabkan Selat Melaka dianggap sebagai salah satu laluan selat antarabangsa yang paling kerap digunakan di lautan dunia (Rothwell \& Stephens, 2017). Wardhana (2015) menyatakan peningkatan trafik perkapalan secara langsung dan tidak langsung mempengaruhi keadaan persekitaran marin di Selat Melaka. Hal ini meningkatkan risiko berlakunya perlanggaran dan pertembungan antara kapal-kapal tersebut sekali gus menyebabkan berlakunya pertumpahan minyak di Selat Melaka. Jabatan Marin Malaysia (2011) melaporkan bahawa terdapat 888 kemalangan yang berlaku di perairan Selat Melaka antara tahun 1978 sehingga 2003, dan terdapat 24 kemalangan antara tahun 2005 hingga 2010. Pertumpahan minyak telah mempengaruhi integriti persekitaran kawasan marin dan pantai dengan kemusnahan dan kerosakan spesies laut, ekosistem dan habitat.

Sungguhpun begitu, pertumpahan minyak yang terjadi akibat perlanggaran dan pertembungan kapal-kapal yang berlaku masih tidak dapat dibendung oleh negara-negara Selat, apabila laluan tersebut disifatkan sebagai laluan transit bagi tujuan antarabangsa. Pengguna laluan selat mempunyai hak, dan tiada sekatan mahupun liabiliti yang patut dikenakan terhadap mereka. (Fasal 38 UNCLOS 1982). Oleh yang demikian, Organisasi Maritim Antarabangsa (2012) dan Rusli et al. (2016) 
membangkitkan persoalan serta isu besar yang melibatkan kuasa yang terhad bagi negara selat untuk menguatkuasakan undang-undang mereka berkenaan pencemaran laut di Selat Melaka. Hal ini kerana pencemaran laut yang berlaku merupakan satu ancaman yang serius terhadap persekitaran dan juga ekosistem marin. Keadaan tersebut menjejaskan sumber pendapatan utama para nelayan yang bergantung harap pada hidupan dan ekosistem marin (Rusli, 2012). Adalah amat penting bagi negara selat untuk mengelakkan kejadian yang berlaku terhadap Torrey Canyon dan Showa Maru daripada berulang melalui penguatkuasaan undang-undang laut terhadap pengguna laluan yang mengakibatkan kerosakan besar terhadap persekitaran marin.

Oleh yang demikian, isu yang dibangkitkan berkaitan dengan persekitaran marin di Selat Melaka, Bahagian XII UNCLOS 1982 menjadi sebahagian daripada perbincangan utama artikel ini. Bahagian ini menekankan perlindungan dan pemeliharaan persekitaran laut dan memberikan tumpuan lebih terhadap pencegahan, pengurangan dan pengawalan pencemaran marin. Kewajipan diletakkan kepada negaranegara Selat untuk melindungi dan memelihara persekitaran laut. Pelaksanaannya boleh dilakukan sama ada dengan mengambil semua langkah yang sesuai atau menjalinkan kerjasama secara global antara negara selat dan negara pengguna untuk merumuskan peraturan dan amalan yang selaras dengan konvensyen. Langkah-langkah tersebut adalah perlu untuk mencegah, mengurangkan dan mengawal pencemaran persekitaran laut. Oleh sebab pencemaran tersebut berada pada tahap yang sangat membimbangkan, adalah penting untuk merujuk Fasal 233 berkaitan dengan langkah-langkah penguatkuasaan dan kerosakan besar yang dilakukan oleh kapal-kapal tersebut.

\section{BAHAGIAN XII KONVENSYEN UNDANG-UNDANG LAUT ANTARABANGSA 1982}

Bahagian XII Konvensyen Undang-Undang Laut 1982 adalah berkaitan dengan pemeliharaan dan pemuliharaan persekitaran marin. Kebanyakan peraturan dalam bahagian tersebut sudah menjadi undang-undang adat yang menuntut seluruh negara mengambil apa-apa jua tindakan yang munasabah bagi mengelakkan pencemaran marin daripada berlaku. (Churchill, n.d.). Tindakan ini dinyatakan dalam Fasal 192 dan 194(1) UNCLOS 1982 dan disokong oleh keputusan yang dibuat dalam kes timbang tara antara Filipina dan China (Lee et al., 2018). Fasal 197 
UNCLOS 1982 juga menggalakkan kerjasama antara negara-negara untuk menghasilkan beberapa peraturan atau standard bagi memelihara ekosistem marin. Bukan itu sahaja, malah Fasal 211 turut meletakkan tanggungjawab secara spesifik kepada negara pantai (coastal state), negara pelabuhan (port state) dan negara bendera (flag state) untuk mengenakan bidang kuasa masing-masing terhadap pengguna-pengguna laluan Selat Melaka. Maka dengan ini dapat disimpulkan bahawa UNCLOS 1982 amat menitikberatkan penjagaan dan pemeliharaan laut daripada apa-apa jua pencemaran (Rayfuse, 2011).

\section{FASAL 233 KONVENSYEN UNDANG-UNDANG LAUT ANTARABANGSA 1982}

Dalam usaha menangani isu pencemaran laut di Selat Melaka, Fasal 233 hendaklah dirujuk dan dibaca bersama-sama Fasal 42 (1) (a) dan (b) Konvensyen Undang-Undang Laut Antarabangsa 1982.

Fasal 233 UNCLOS 1982 menyatakan:

...if a foreign ship other than those referred to in section 10 has committed a violation of the laws and regulations referred to in article 42, paragraph 1(a) and (b), causing or threatening major damage to the marine environment of the straits, the States bordering the straits may take appropriate enforcement measures and if so shall respect mutatis mutandis the provisions of this section.

Fasal 42 UNCLOS 1982 pula adalah seperti yang berikut:

1. Subject to the provisions of this section, States bordering straits may adopt laws and regulations relating to transit passage through straits, in respect of all or any of the following:

a) the safety of navigation and the regulation of maritime traffic,as provided in article 41;

b) the prevention, reduction and control of pollution, by giving effect to applicable international regulations regarding the discharge of oil, oily wastes and other noxious substances in the strait;... 
Daripada fasal tersebut dapat dilihat bahawa peraturan-peraturan ini merujuk tanggungjawab yang perlu dilaksanakan oleh negara selat terhadap pengguna kapal yang melanggar peraturan dengan berbuat kerosakan besar terhadap persekitaran marin. Antara peraturan serta langkah yang diambil oleh negara selat untuk menangani masalah yang dihadapi adalah dengan membuat perubahan terhadap peraturan sedia ada, iaitu mempertingkatkan sistem keselamatan serta pencemaran, termasuklah yang dibentuk di bawah Konvensyen Antarabangsa Mengenai Keselamatan di Laut (SOLAS) 1974, Konvensyen Antarabangsa dalam Menangani Pencemaran dari Kapal (MARPOL) 1973/1978, Peraturan Antarabangsa untuk Menghindari Pertembungan di Laut (COLREG) 1972 dan banyak lagi (Hanizah, 2001).

Kepentingan peraturan tersebut dibangkitkan semasa sesi perundingan akhir antara Indonesia, Malaysia dan Singapura pada tahun 1982. (Dyke, 2008). Walaupun hal ini dikatakan tidak selari dengan kelebihan laluan tersebut sebagai laluan transit, negara selat tersebut boleh mengguna pakai Fasal 233 dan 42 demi memastikan keselamatan navigasi, pengawalan lalu lintas maritim yang baik serta pencegahan dan pengurangan pencemaran. Pemeriksaan fizikal pada kapal yang menjadi punca pencemaran juga hendaklah dilakukan bagi membuktikan bahawa terdapatnya pelanggaran undang-undang laut antarabangsa (Fasal 220(2) UNCLOS 1982).

Secara fizikalnya, Fasal 233 tampak tidak rumit, namun terdapat perbezaan dari segi tafsiran yang meninggalkan jurang dalam rangka pengawalseliaan untuk melindungi persekitaran laut di Selat Melaka (Rusli et al., 2016). Semua peruntukan di atas tidak membincangkan fasal berkaitan dengan prosedur dan penguatkuasaan undang-undang (Sativale, 2001). Oleh itu, tidak ada garis panduan yang jelas untuk membantu negara-negara ini dalam usaha melindungi dan memelihara persekitaran laut. Hal ini menunjukkan bahawa negara-negara tersebut tidak mempunyai hak untuk campur tangan walaupun mereka menegaskan bahawa campur tangan demi melindungi persekitaran laut mereka. Dalam erti kata lain, kebebasan navigasi hendaklah sentiasa menjadi keutamaan di Selat Melaka sebagai laluan antarabangsa (Rusli et al., 2016).

\section{Definisi dan Konsep Fasal 233 UNCLOS 1982}

Terdapat pelbagai perbincangan tentang kekurangan Fasal 233 yang menjadikannya lebih sukar bagi negara selat untuk mengambil tindakan 
terhadap kapal-kapal yang terlibat. Pertama sekali, Rusli et al. (2016) menyatakan bahawa negara selat tidak mempunyai hak untuk menghalang atau memintas laluan kapal di bawah Fasal 38(1), 42(2) dan 44. Dalam erti kata lain, bidang penguatkuasaan mereka terhadap kapal-kapal yang membuat kerosakan di perairan Selat Melaka menjadi terhad dan hanya terpakai dalam kes yang terkecuali (Dyke, 2008). Kendatipun demikian, George (2004) berpendapat bahawa negara selat masih mempunyai hak dan tanggungjawab untuk mengenakan tindakan terhadap kapal-kapal yang gagal mengikut peraturan pelepasan bawah kapal sebanyak 3.5 meter.

Kedua, terdapat kekaburan pada Fasal 233 UNCLOS 1982. Bahagian pertama Fasal 233 mengandungi frasa "causing or threatening major damage" dan maksud yang dibawa adalah tidak selari dengan peruntukan yang lain di bawah UNCLOS 1982. Tidak dapat dinafikan bahawa peruntukan tersebut membenarkan negara selat mengambil langkah penguatkuasaan yang munasabah terhadap kapal-kapal yang membuat kerosakan, namun fasal tersebut tidak menyatakan bahawa hak kapal tersebut di bawah laluan transit akan turut terhalang (Fasal 38 UNCLOS 1982). Semasa menyertai Persidangan UN mengenai Undang- undang Laut Ketiga, delegasi Spain memberikan pandangan mengenai hal ini dan menyatakan bahawa Fasal 233 mendiskriminasi hak negara selat dalam menangani pencemaran yang berlaku di lautan mereka (Yturriaga, 1992). Koh (1982) turut mencadangkan dua faktor yang seharusnya dianggap penting dalam menganalisis frasa tersebut, iaitu: (1) Kemalangan yang berlaku ialah hasil daripada pelanggaran peraturan navigasi dan; (2) tahap kerosakan mengikut jenis kapal dan barang yang dibawa.

Bagi bahagian kedua Fasal 233, frasa "appropriate enforcement measures" juga terbuka kepada pelbagai tafsiran. Tullio Scovazzi dari Universiti Milan (1995) menyatakan bahawa frasa tersebut seharusnya merujuk keizinan yang diberikan kepada negara selat untuk menghalang laluan kapal yang berkenaan. Beliau menambah bahawa tiada imuniti sepatutnya diberikan kepada kapal tersebut untuk menangani pencemaran laut. Tambahan pula, kenyataan tersebut disokong oleh seorang arkitek daripada Konvensyen Undang-Undang Laut 1982, Satya Nandan (2001) yang menyatakan bahawa penguatkuasaan undang-undang tersebut seharusnya dilakukan melalui negara bendera (flag state) melainkan kapal tersebut telah secara sukarela memasuki laluan Selat Melaka.

Bukan itu sahaja, malah Caron \& Oral (2014) turut menimbulkan isu lain di Selat Melaka yang mungkin dikaitkan dengan Fasal 233. Antaranya 
termasuklah, negara selat tiada hak untuk menghalang pelayaran kapal asing walaupun kapal itu berkemungkinan menyebabkan kerosakan besar terhadap perairan Selat Melaka. Mereka juga menyatakan bahawa ketiadaan peruntukan tentang liabiliti, ganti rugi serta syarat yang wajar dikenakan kepada kapal asing menyebabkan kapal asing memandang ringan isu keselamatan perairan Selat Melaka. Bukan itu sahaja, malah tiada peruntukan dalam UNCLOS 1982 yang membenarkan Negara Selat mengambil tahu jenis kapal dan muatan yang dibawa kapal asing. Jika hak tersebut diberikan, negara selat serta pengguna sudah pasti dapat bertukar maklumat sekali gus dapat menjamin penyediaan sistem kawalan yang mencukupi terutamanya terhadap kapal yang membawa bahan nuklear atau bahan berbahaya. Langkah berjaga-jaga juga dapat diambil untuk menangani sebarang pencemaran yang bakal berlaku. Jelas kelihatan di sini bahawa dengan ketiadaan definisi yang jelas pada terma "major damage" dan "appropriate enforcement measures" menyebabkan peruntukan tersebut disalah tafsir dan disalah erti oleh pihak berkenaan.

Mohd Hazmi Rusli (2016) daripada Universiti Sains Islam Malaysia menyatakan bahawa semua frasa tersebut berkaitan rapat dengan terma "good faith" di bawah Fasal 26 Vienna Convention on the Law of Treaties. Mengikut Fasal 26 serta beberapa kes yang dirujuk seperti kes Nuclear Tests dan Gabcikovo-Nagymaros, dapat disimpulkan bahawa langkah penguatkuasaan yang diambil terhadap pengguna kapal yang melakukan kerosakan besar terhadap persekitaran marin hendaklah sesuai dan munasabah yang menepati tujuan utama Fasal 233 untuk melindungi dan memelihara laluan selat sebagai laluan antarabangsa dapat direalisasikan.

Oleh yang demikian, berdasarkan senario di atas, jika masih tiada definisi yang jelas tentang kedua-dua frasa tersebut, bidang kuasa negara selat untuk menghalang laluan kapal yang membuat kerosakan berterusan menjadi terhad. Keadaan ini hanya boleh berubah jika terdapat definisi dan garis panduan yang lebih jelas tentang Fasal 233 bagi melindungi dan memelihara persekitaran marin dan pantai negara selat.

\section{PELAKSANAAN FASAL 233 UNCLOS 1982 OLEH NEGARA SELAT}

Dalam usaha mencegah, mengurangkan dan mengawal pencemaran daripada berlaku, terdapat juga fasal lain di bawah UNCLOS 1982 yang boleh diguna pakai untuk melindungi perairan Selat Melaka. Dalam perkataan lain, penguatkuasaan undang-undang tersebut tidak hanya 
menggunakan Fasal 233 dan 42 UNCLOS 1982. Di bawah Fasal-fasal lain UNCLOS 1982 tersebut ada dinyatakan tanggungjawab yang perlu digalas oleh negara selat terhadap Selat Melaka.

\section{Peraturan Lain di Bawah UNCLOS 1982 yang Berkaitan dengan Fasal 233}

\section{(1) Fasal 39}

Fasal 39 UNCLOS 1982 menuntut kapal-kapal serta kapal terbang yang melalui laluan transit untuk mematuhi kewajipan yang telah digariskan, iaitu meneruskan pelayaran tanpa sebarang penangguhan melalui selat; untuk tidak melakukan sebarang ancaman atau kekerasan terhadap kedaulatan, wilayah dan kebebasan politik negara selat; untuk tidak melakukan apa-apa jua aktiviti melainkan secara cekap dan berterusan, dan disebabkan keadaan yang tak dapat dielakkan dan peraturan-peraturan lain yang dinyatakan di Bahagian III UNCLOS 1982.

Tambahan pula, antara tugas Negara Selat terhadap kapal-kapal yang menggunakan laluan transit tersebut termasuklah:

(i) mematuhi segala peraturan antarabangsa dan pelaksanaannya bagi tujuan keselamatan di laut, termasuk undang-undang antarabangsa yang berkaitan dengan perlanggaran kapal di laut dan juga bagi tujuan mengelakkan, mengurangkan dan mengawal pencemaran daripada kapal. (Fasal 39(2) UNCLOS 1982);

(ii) tidak melakukan apa-apa kajian atau aktiviti pemerhatian tanpa keizinan dan kebenaran daripada negara selat. (Fasal 40 UNCLOS 1982);

(iii) menghormati laluan laut dan Skim Pemisahan Lalu Lintas (TSS). (Fasal 41(7) UNCLOS 1982).

\section{(2) Fasal 41}

Fasal 41 menggalakkan Negara Selat untuk menyediakan laluan perairan dan Skim Pemisahan Lalu Lintas atau Trafic Saperation Scheme (TSS) demi keselamatan kapal-kapal yang melalui laluan selat. Laluan yang disediakan hendaklah mematuhi syarat yang dinyatakan antaranya termasuklah mematuhi undang-undang antarabangsa, dapat diterima 
pakai oleh organisasi antarabangsa yang berwibawa, serta laluan tersebut hendaklah ditandai di atas peta. Fasal 41(5) seterusnya meminta kerjasama antara Negara Selat untuk menaik taraf laluan kapal dan TSS tersebut.

\section{(3) Fasal 43}

Fasal 43 menggesa Negara Selat untuk bekerjasama dengan memainkan peranan dalam sebarang penubuhan dan penyelenggaraan serta peningkatan usaha demi keselamatan perairan Selat Melaka. Oleh itu, dapat dilihat bahawa Fasal ini secara tidak langsung menggesa negara selat untuk melibatkan pihak-pihak yang berkepentingan untuk memberikan sumbangan dan mempertingkatkan keselamatan perairan serta melindungi persekitaran marin.

\section{Insiden yang Melibatkan Pelaksanaan Fasal 233 oleh Negara Selat}

Menurut Rusli (2011), pelaksanaan Fasal 233 telahpun dijalankan dan dikuatkuasakan di Selat Melaka. Hal ini dapat dilihat melalui pengurangan kemalangan yang berlaku sejak tahun 1975 dan 2000. Terdapat enam kematian akibat daripada kemalangan yang menyebabkan kerosakan besar di persekitaran marin. Sejurus selepas UNCLOS 1982 dilaksanakan pada tahun 1994, terdapat hanya tiga kemalangan yang terjadi di Selat Melaka yang menyebabkan Negara Selat pada masa itu mengguna pakai Fasal 233 untuk menangani isu kerosakan besar yang mencemarkan laut. Arsana (2011) menyenaraikan tiga kejadian tersebut yang melibatkan (1) MT Natuna Sea; (2) MV Ostende Max dan (3) MV Waily dan MT Bunga Kelana.

\section{(i) MV Natuna Sea (Mark, 2001)}

Pada 3 Oktober 2000, MT Natuna Sea sedang dalam perjalanan dari Timur Tengah ke China. Sebelum fajar, pada kira-kira pukul 6.15 pagi, kapal tangki tersebut terlanggar Terumbu Karang Batu Berhanti di Lintang di perairan Indonesia dan menyebabkan 4 tangki minyak pecah dan kira-kira 7000 tan minyak tumpah ke laut. Kejadian tersebut tidak menghalang aliran lalu lintas di selat tetapi minyak merebak dengan cepat kerana aliran air pasang yang agak kuat di selat. Tanpa berlengah, amaran navigasi dikeluarkan untuk memberikan amaran kepada kapal-kapal tanah dan minyak di selat. Singapura, sejurus menerima amaran tersebut, melakukan apa-apa jua cara untuk melindungi kawasan sensitif di perairan mereka seperti 
Pantai Sentosa dan Pantai Timur, lagun ikan lumba-lumba merah jambu, pintu masuk ke Marina Bay dan kawasan penternakan ikan. Indonesia pula melepaskan kapal dan membenarkannya belayar ke Singapura bagi tujuan pengeringan dok. Berikutan dengan kejadian ini, Captain Mark dari Singapura yang merupakan Penolong Pengarah Bahagian Pelabuhan dan Perkapalan mengatakan bahawa kerjasama adalah penting antara negara selat untuk mengelakkan sebarang insiden pertumpahan minyak daripada mencemarkan perairan pantai. Beliau menambah adalah lebih baik mencegah daripada mengubati kerana semestinya menjimatkan kos dan wang daripada menanggung kesannya.

\section{(ii) MV Ostende Max (Rusli, n.d)}

Pada tahun 2009, MV Ostende Max, sebuah kapal Britain sedang dalam perjalanan dari Korea Selatan ke Emiriah Arab Bersatu ketika berlanggar dengan MT Formosa Product Brick, sebuah kapal Liberia. Menurut mStar \& The Star (2009) tiada pertumpahan minyak yang berlaku di kawasan kebakaran tersebut yang membawa muatan 58000 tan cecair naphtha dalam kejadian yang berlaku kira-kira 30 kilometer dari pantai pelancongan Port Dickson. Kedua-dua kapal tersebut tidak dapat meneruskan pelayaran. Kendatipun demikian, adalah amat berbahaya bagi kedua-dua kapal untuk terus dibiarkan di perairan Selat Melaka kerana hal ini mengancam keselamatan perairan. Akhirnya MV Ostende Max kemudiannya ditunda ke tempat yang selamat, iaitu di kawasan pelabuhan Port Dickson. Tiga orang krewnya dihantar ke Hospital Port Dickson untuk rawatan akibat kecederaan. Dapat dilihat di sini bahawa ancaman terhadap perairan dapat dielakkan oleh negara selat dengan menunda pelayaran MV Ostende Max.

(iii) MV Waily dan MT Bunga Kelana 3 (Rusli, 2011)

Pada 25 Mei 2010, MV Waily berlanggar dengan MT Bunga Kelana dari Malaysia di TSS menyebabkan 2000 tan minyak tumpah ke laut. Pihak berkuasa Maritim dan Pelabuhan Singapura (MPA) telah menyelaraskan pembendungan dan pembersihan tumpahan minyak yang terhasil. Setelah pemberitahuan kejadian itu, MPA segera menghantar empat peronda dan pasukan kecemasan ke kawasan yang terjejas. MPA juga mengaktifkan syarikat tindak balas tumpahan minyak. Bukan itu sahaja, lebih daripada 85 anggota berada di tapak sebagai sebahagian daripada usaha membendung dan membersihkan minyak. MPA juga telah memaklumkan 
marin, pusat sukan laut, terminal feri dan kemudahan tepi laut yang lain untuk persediaan akibat kesan yang mungkin timbul daripada tumpahan minyak dan usaha membersihkan tumpahan minyak dilakukannya. Walau bagaimanapun, tumpahan minyak dan usaha pembendungan dan pembersihan tidak menjejaskan lalu lintas.

\section{CADANGAN BAGI PENAMBAHBAIKAN TERHADAP ISU PENCEMARAN LAUT DI SELAT MELAKA DAN KEWAJIPAN NEGARA SELAT}

\section{Memberikan Definisi yang Jelas pada Frasa "Major Damage”}

Menurut George (2004), tanpa definisi yang jelas terhadap frasa "major damage", pelaksanaan undang-undang antarabangsa terhadap laluan Selat Melaka akan menjadi lebih terhad dan tidak efisien. Tidak dapat dinafikan UNCLOS 1982 mengiktiraf hak laluan transit kapal-kapal yang melalui Selat Melaka sebagai laluan antarabangsa, iaitu laluan mereka hendaklah tidak terhalang dan dihalang oleh negara selat. Hanya jika terdapat ancaman bahawa berlakunya kerosakan besar terhadap persekitaran marin, maka laluan yang digunakan oleh kapal yang terlibat akan dihalang oleh negara Selat. Namun begitu, UNCLOS 1982 tidak menyatakan sejauh mana kerosakan besar yang perlu berlaku untuk mewajarkan hak negara selat dalam menghalang laluan tersebut (Rusli, 2012).

Jika terma "major damage" dilaksanakan secara terhad, maka hal ini melanggar Fasal 192 yang meletakkan kewajipan am atas negara selat untuk memelihara dan melindungi persekitaran marin. Oleh yang demikian, Fasal 233 memerlukan definisi yang lebih jelas untuk memastikan pelaksanaan undang-undang yang lebih efektif. Sungguhpun Fasal 233 boleh dipinda, namun hendaklah konsisten dengan Fasal-fasal lain yang terdapat dalam UNCLOS 1982.

Rusli et al. (2016) menyenaraikan beberapa cadangan pindaan yang boleh dilakukan, antaranya termasuklah:

(i) Garis perbezaan yang jelas dan nyata dilakukan pada Bahagian IIIUNCLOS 1982 dan Fasal 233 sama ada usaha-usaha yang dilakukan terpakai kepada semua laluan selat atau laluan selat sebagai laluan antarabangsa; 
(ii) Frasa "major damage" atau kerosakan besar di bawah Fasal 233 diberikan definisi yang lebih nyata dan jelas; dan

(iii) Fasal 233 seharusnya menyenaraikan jenis pencemaran yang berlaku untuk membolehkan Negara Selat mengambil tindakan terhadap kapal yang terlibat.

Sebagai kesimpulan, kedua-dua instrumen antarabangsa, iaitu UNCLOS 1982 dan Organisasi Maritim Antarabangsa (IMO) memainkan peranan yang amat penting dalam penyediaan garis panduan bagi negara-negara berkaitan, terutamanya Negara selat, untuk bersamasama melaksanakan segala usaha bagi menangani pencemaran laut, mengurangkan risiko pencemaran marin dan meningkatkan keselamatan navigasi di Selat Melaka.

\section{Menggantikan Hak Laluan Transit kepada Hak Laluan Ikhlas Tanpa Had}

Secara amnya, Fasal 38 UNCLOS 1982 mengiktiraf hak laluan transit kepada kapal asing. Namun begitu, hal yang sebaliknya berlaku kepada kapal asing jika hak laluan ikhlas dilaksanakan di Selat Melaka. Kapal selam dikehendaki muncul di permukaan air apabila melalui laluan selat, pesawat asing tidak mempunyai kebebasan untuk terbang di ruang udaranya. Daripada situasi tersebut, dapat dilihat bahawa Fasal ini tidak memberikan kebebasan kepada kapal asing untuk berbuat sebarang tindakan yang boleh memberikan ancaman kepada Negara Selat dan menuntut mereka untuk meneruskan perjalanan tanpa henti sepanjang laluan ikhlas tersebut. Pelaksanaan Fasal ini secara tidak langsung dapat menjamin keselamatan perairan Negara Selat daripada sebarang ancaman atau kuasa yang boleh mengganggu gugat keamanan Negara Selat.

Fasal 233 pula berkaitan dengan bidang kuasa penguatkuasaan yang terpakai pada laluan selat yang digunakan sebagai laluan antarabangsa. Langkah penguatkuasaan undang-undang akan diambil terhadap kapal asing yang melanggar undang-undang yang dibuat di bawah Fasal 42 perenggan 1(a) dan (b), iaitu yang menyebabkan atau mengancam kerosakan besar terhadap persekitaran marin. Namun begitu, UNCLOS 1982 tidak menyatakan jenis-jenis laluan selat yang digunakan sebagai laluan antarabangsa yang berhak menggunakan Fasal 233. 
Bahagian 2 Fasal 233 menyatakan yang berikut:

However if a foreign ship... has committed a violation of the laws and regulations referred to in article 42, paragraph 1(a) and (b), causing or threatening major damage to the marine environment of the straits, the States bordering the straits may take appropriate enforcement measures. (emphasis added)

Dapatlah disimpulkan bahawa terdapat perkaitan antara Fasal 233 dan Bahagian III UNCLOS 1982. Fasal 233 juga menyebut Fasal 42, yang merupakan sebahagian daripada Bahagian III. Fasal 42 pula diguna pakai bagi selat yang digunakan sebagai laluan antarabangsa. Negara selat berasa bahawa mereka tidak mempunyai hak untuk melakukan apa-apa jua cara untuk menangani pencemaran laut. Hal yang demikian kerana hak laluan transit diberikan kepada kapal asing. Laluan tersebut seharusnya dikenakan hak laluan ikhlas selari dengan Bahagian II, Seksyen 3 UNCLOS 1982 (Rusli, 2011). Jika hak laluan transit digantikan dengan hak laluan ikhlas tanpa had, Malaysia dan Indonesia mempunyai hak untuk mengenakan apa-apa jua undang-undang dan peraturan terhadap kapal-kapal yang melanggar peraturan berkaitan dengan pencemaran marin tanpa menunggu berlakunya kejadian sebenar yang akan memberikan kerosakan besar terhadap Selat Melaka. Malah, tindakan yang diambil tidak hanya terhad pada Fasal 42, dan langkah-langkah berjaga dapat dilakukan terlebih dahulu oleh Negara Selat.

Dengan pelaksanaan hak laluan ikhlas tanpa had, hal ini dapat memperkuat penguatkuasaan undang-undang Negeri Selat dalam usaha mentadbir laluan selat.

\section{KESIMPULAN}

UNCLOS 1982 dianggap sebagai perlembagaan yang mengawal selia perlindungan dan pemeliharaan persekitaran marin. Perkaitan antara Bahagian III dan Fasal 233 Bahagian XII UNCLOS 1982 adalah tidak jelas. Perkataan yang digunakan juga tidak jelas, dan mengakibatkan kekeliruan dalam pelaksanaannya. Fasal 233 hanya membenarkan tindakan undang-undang diambil terhadap kapal asing yang menyebabkan atau mengancam untuk berbuat kerosakan besar terhadap persekitaran marin di Selat Melaka. Disebabkan tiada definisi yang jelas, persoalan lain timbul terhadap kapal-kapal yang hanya berbuat kerosakan kecil di Selat Melaka. 
Maka, dapat disimpulkan di sini bahawa Fasal 233 tidak efektif dalam melindungi dan memelihara persekitaran marin di Selat Melaka. Walaupun terdapat pelbagai cadangan bahawa kerjasama antara negara-negara Selat Melaka perlu dinaik taraf, adalah amat penting untuk meminda undangundang yang baharu bagi melindungi persekitaran marin di laluan selat yang digunakan sebagai laluan antarabangsa.

\section{RUJUKAN}

Arsana, I. M. A. (2011). Insiden Selat Malaka from. Diakses daripada http:// us.detiknews.com/read/2011/04/13/082414/1615124/103/insiden-selatmalaka

Hanizah Idris. (2001). Isu kemalangan kapal dan pencemaran laut di Selat Melaka: Satu tinjauan. JATI-Journal of Southeast Asian Studies, 6, 119-137.

Koh, T. (2007). Chairmans Introductory Remarks. Singapore Perspectives, 1-3. doi: 10.1142/9789812708243_0001

Koh, T. (2012). Straits used for international navigation: Some recent developments. The Regulation of International Shipping: International and Comparative Perspectives. doi: 10.1163/9789004202443_003

Lee, S \& Bautista, L. (2018). Part XII of the United Nations Convention on the law of the sea and the duty to mitigate against climate change: Making out a claim, causation and related issues. Ecology Law Quarterly, 45, 129-156.

Mark, H. E. S., (2001). Changes on OSR system in major countries/ recent movement of compensation scheme: Natuna sea incident - Singapore's experience. PAJ Oil Spills Symposium 2001.

Nandan, S. N., \& Anderson, D. H. (2001). Straits used for international navigation: A commentary on Part III of the United Nations Convention on the Law of the Sea 1982. British Yearbook of International Law, 60(1), 159-204. doi: 10.1093/bybil/60.1.159

Persatuan Bangsa-bangsa Bersatu. (1982). Konvensyen Undang-Undang Laut Antarabangsa 1982.

Rothwell, D., G., O. E. A., Scott, K., \& Stephens, T. (2017). The Oxford handbook of the law of the sea. Oxford University Press.

R.Churchill, R. (n.d.). The LOSC regime for protection of the marine environment - fit for the twenty-first century? Research Handbook on International Marine Environmental Law, 3-30. doi: 10.4337/9781781004777.00008

R. Sativale. (2003). Transit passage in the Straits of Malacca. MIMA Bulletin, $11-2$.

Rayfuse, R. (2011). Robin Warner, protecting the oceans beyond national jurisdiction: Strengthening the international law framework. Ocean Yearbook Online, 25(1), 487-489. doi: 10.1163/22116001-92500022 
Rusli, H., Dremliuga, R., \& Talaat, W. I. (2016). Legal framework on the marine environment protection of straits used for international navigation: Has it been effective in the Straits of Malacca and Singapore? Journal of East Asia and International Law, 9(1), 75-76. doi: 10.14330/jeail.2016.9.1.04

Rusli, M. H. B. M. (2012). The application of transit passage regime in straits used for international navigation: A study of the Straits of Malacca and Singapore. Asian Politics \& Policy, 4(4), 549-569. doi: 10.1111/j.19430787.2012.01374.x

Rusli, M. H. B. M. (2012). Navigational regimes through straits used for international navigation: A study of the Straits of Malacca and Singapore. MIMA Bulletin, 19(1), 4-13.

Rusli, M. H. B. M. (2012). Navigational hazards in international maritime chokepoints: A study of the Straits of Malacca and Singapore. Journal of International Studies, 8, 47-75.

Rusli, M. H. B. M. (2011). The application of compulsory pilotage in straits used for international navigation: A study of the Straits of Malacca and Singapore. Asian Politics and Policy, 3(4), 501-526. doi:10.1111/j.19430787.2011.01291.x

Rusli, M. H. B. M., Mustafa, M. B., \& Wan Izatul Asma Wan Talaat. (2013). Replacing the transit passage regime with freedom of navigation in the Strait of Malacca: A case study with special reference to the Korea Strait. Ocean \& Coastal Management, 78, 25-34. doi: 10.1016/j.ocecoaman.2013.03.00.

Scovazzi, T. (1995). Management regimes and responsibility for international straits. Marine Policy, 19(2), 137-152. doi: 10.1016/0308-597x(94)00007-f

The Corfu Channel Case (Merits) Judgment of April 9th, 1949. (1949). The Hague International Court of Justice.

Wardhana, Nanditya Darma. (2015). The Implications of the Implementations of Part III of the United Nations Convention on the Law of the Sea (UNCLOS 1982) 1982 to the Safety of Navigation and Marine Environmental Protection in the Straits used for International Navigation: The Review of Policy and Cooperation, and Future Direction of the Cooperative Mechanism in the Straits of Malacca and Singapore (unpublished Dissertations). World Maritime University, 501.

Yturriaga, J. A. D. (1992). Straits used for international navigation - A Spanish perspective. Verfassung in Recht Und Übersee, 25(1), 90-91. doi: 10.5771/0506-7286-1992-1-90. 